\title{
ピラーアレイ構造表面による近接場光の波長制御に関する研究 Spectral Control of Near-Field Radiation through Pillar Array Structure
}

\author{
ウオンサオスブ ナパトソン（東工大） \\ 学芦田 友祐（東工大） \\ 正 平島 大輔 (データフォーシーズ) \\ ○正 花村 克悟 (東工大)
}

Vongsoasup Naphatsorn, Yusuke Ashida, Daisuke Hirashima and Katsunori Hanamura

Tokyo Institute of Technology, 2-12-1 O-okayama, Meguro-ku, Tokyo 152-8550

\begin{abstract}
Spectral control of near-field radiation was achieved through pillar array surface structures. Electromagnetic field around the pillar array structures which were set up face to face was clarified by solving Maxwell's equation numerically. Normalized radiative flux was estimated for the case of nickel and tungsten emitters and the case of nickel and $\mathrm{GaSb}$ emitters. It was disclosed that even if the emitters was made of different materials, near-field radiative flux was enhanced for a specified band of frequency by tuning the height of pillar and/or the width between pillars. In the case of nickel and $\mathrm{GaSb}$ emitters, the radiative flux with a range of frequency from 10 to $20 \times 10^{14} \mathrm{rad} / \mathrm{s}$ was increased by a factor of three compared with the case of smooth surfaces.
\end{abstract}

Key Words: Near-Field Radiation, Spectral Control, Pillar Array Structure

1. はじめに

周期的ピラー構造を有する金属表面では,ピラー,隙間, ビラーといった構造に MIM (Metal-Insulator-Metal)やIMI 構 造と同様の表面プラズモンボラリトンが誘起され，それら が干涉することで近接場ふく射輸送の波辰制御が可能とな る.このビラー側面に励起される表面ブラズモンボラリト ンは, 半無限平板間で励起される表面ブラン゙モンポラリト ンとほとルど一致することが分かっている.すなわた，ビ ラー幅, 溝幅, ピラー高さを制御し，表面ブラズモンボラ リトンの共鳴条件をチューニングすることにより，異種の 材料間においても，ピラー構造による近接場ふく射輸送の 波長制御が実現可能であると考えられる.

そこで，本研究では異種の材料間において，溝幅やビラ 一高さを変化させながら，ふく射輸送の評価を行った。数 值計算仕，まず物性が周知されており，FDTD 法に容易に 適用することができるニッケルとタングスデンを用い，そ の後，TPV 発電の系に近い金属(ニッケル) と半導体（ガ リウムアンチモン)を用いて,ふく射輸送の評侕を行った.

\section{2. 計算手法}

図 1 に向かい合うビラーアレイ構造表面の模式図を示す. 表面間距離を $d$, ビラー構造のビッチを $p$, ビラー高さを $h$, ピラー間隙間を $w$, ピラートッブ面を $a \times a$ とする. 本䂺究 ではマックスウェル方程式を, FDTD 洁を用いて電磁場解 析を行い，摇動電磁気学によりふく射輸送を評価した ${ }^{(1)}$. 本研究では，複数の周波数成分を持つ正弦波ガウシアン変 調パルスを放射させることにより，1 回の計算で複数の周 波数成分の対応関係を求めた。ささら，一度に周期性を考

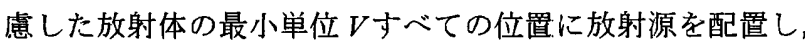
位相差を乱数で与えることにより，それぞれの放射源の相 互作用を減らした。この計算は位相差に乱数を用いている ため，1回の計算による結果は変動が大きくなってしまう. そこで約 100 回計算を行い，それらの結果の平均值をとる ことにより，収束させた。

\section{3. 計算結果}

3.1 ニッケル放射体ータングスデン受光体

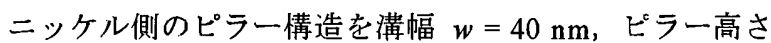
$h=200 \mathrm{~nm}$ で固定し, タングステン側のビラー構造を溝幅 $w=80 \mathrm{~nm}$ とし, ピラー高さを $100 \sim 300 \mathrm{~nm}$ まで $50 \mathrm{~nm}$ 刻 みで変化させ，タングステン，ニックル間のふく射流束を 計算した。 その結果を Fig. 2 に示す。この綕果から、ニッ ケルの溝幅 $40 \mathrm{~nm}$, ビラー富さ $200 \mathrm{~nm}$ の場合のピーク周波 数とほ代一致していた，タングステンの满幅 $80 \mathrm{~nm}$, ピラ 一高さ $150,200,250 \mathrm{~nm}$ の場合において，ふく射流束はそ れ以外のピラー高さに比べて促進されていることが分かる.

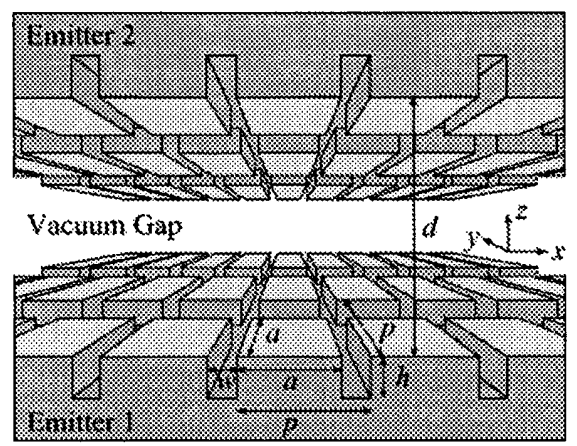

Fig.1 Schematic diagram of pillar array structure

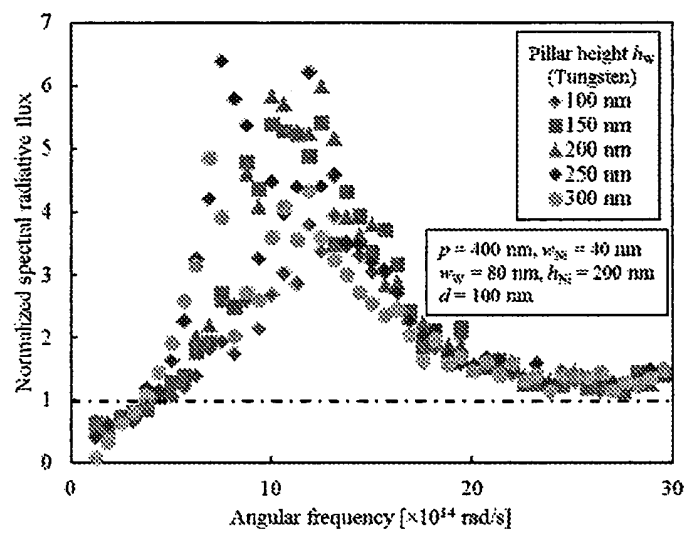

Fig.2 Normalized radiative flux between pillar array structures made of Nickel and Tungsten 


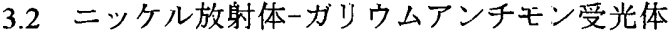

まずニッケル $(1000 \mathrm{~K})$ - ガリウムアンチモン $(300 \mathrm{~K})$ の半無限平板間のふく射輸送の解析解之数值解の結果を Fig.3に示す．このとき，真空空間を $100 \mathrm{~nm}$ とし，綄軸は ボーズ・アインシュタインのエネルギー分布関数で規格化 したふく射流束である．数值計算結果恃解析解とよく一致 していることがわかる．さらにニッケル平板間に比べて， 低周波数域においてふく射輸送量は抑制され，高周波数に おいて促進されていることがわかる．低周波数における二 ッケル平板間のふく射輸送は $\mathrm{s}$ 偏光が支配的である。 しか し, ニッケルーガリウムアンチモン平㤆間においては Fig.4 に示すように, $\mathrm{p}$ 偏光に関してはニッケル平板間とほとん ど変わらないものの， $\mathrm{s}$ 偏光に関しては大きく異なり，二 ッケル - ガリウムアンチモン平板間では広い周波数域にわ たって大きなふく射流束が分布している. 次に $\mathrm{s}$ 偏光およ び $\mathrm{p}$ 偏光のふく射流束スペクトルを，ニッケル平板間と比 較した結果を Fig.5 に示す。縦軸はボーズ・アインシュタ インのエネルギー分布関数で規格化したふく射流束，横軸 は角周波数である。この結果より, $\mathrm{s}$ 偏光は約 $5 \times 10^{14} \mathrm{rad} / \mathrm{s}$ 以下においてはニッケル平板間の方がふくく射流束は大きい が，それ以上の周波数域ではニッケルーガリウムアンチモ ン平板間の方が大きくなっている.また $\mathrm{p}$ 偏光はすべての 周波数域に抒いてニックル平板間の方がふく射流束は大き いことが分かる。これにより，ニッケルーガリウムアンチ モン平板間のふく射輸送が低周波数側において抑制されて いるのも高周波数側で促進されているのもすべて $\mathrm{s}$ 偏光に 起因していると考えられる.

次に周期的ビラ一構造を施したニッケル - ガリウムアン チモン間のふく射輸送について考察する.ビラー構造は, 周期 $p=400 \mathrm{~nm}$, 溝幅 $w=40 \mathrm{~nm}$, ピラー幅 $a=360 \mathrm{~nm}$, ピラー高さ $h=200 \mathrm{~nm}$ とし, 真空ギャッブ $d=100 \mathrm{~nm}$ 計算を行った。 今囘はニッケル - ガリウムアンチモン間に お汁るピラー構造による近接場ふく射輸送促進機構の有無 の確認を目的とするため，上ドビラー構造で同じ構造を用 いた. その結果を Fig.6 に示す。紸軸は平板間のふく射流 束で規格化したふく射流束である．比較のため周期的ピラ 一構造を施したニッケル間の結果も示寸。この結果より， ニッケル平板間に比バるとふく射輸送の促進効果は小さい ものの, ニッケル - ガリウムアンチモン間においてもビラ 一構造に上る促進効果は得られることが分かった。また低 周波数域において，ふく射流束は平板間に比べてニッケル 間においては抑制されているが，ニッケルーガリウムアン チモン間においては促進されている。これは上述のように ニッケル平板間のふく射輸送に打いては低周波数域で $\mathrm{s}$ 偏 光が支配的であったため，ビラー構造の付与沉よる $\mathrm{s}$ 偏光 の抑制効果が大きかったが，ニッケルーガリウムアンチモ ン間りふく射輸送においては低周波数域でニッケル間に比 べて $\mathrm{s}$ 偏光が顕著でないため, $\mathrm{s}$ 偏光の抑制効果が顕著に 現れなかったと考えられる。

\section{4.まとめ}

異種の材質に対して，溝幅やピラー高さを調整し，ピラ 一側面に励起される表面ブラズモンポラリトンの共鳴お上 び干涉する周波数のチューニングを行うことにより，近接 場ふく射輸送が促進される。

\section{参考文献}

(1)平島, 他, 機論, 77-782, (2011), 1978.

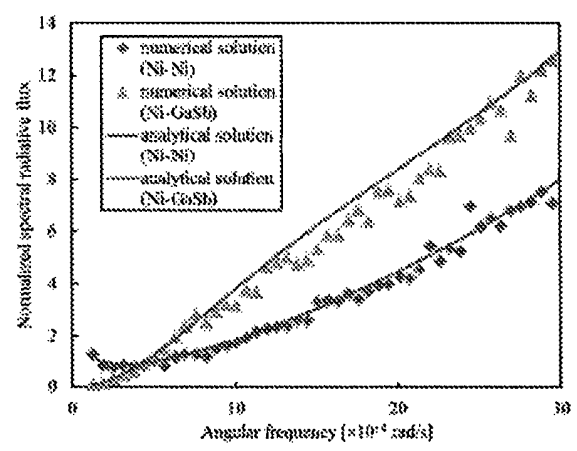

Fig. 3 Comparison between analytical and numerical solutions between planes made of Nickel and GaSb

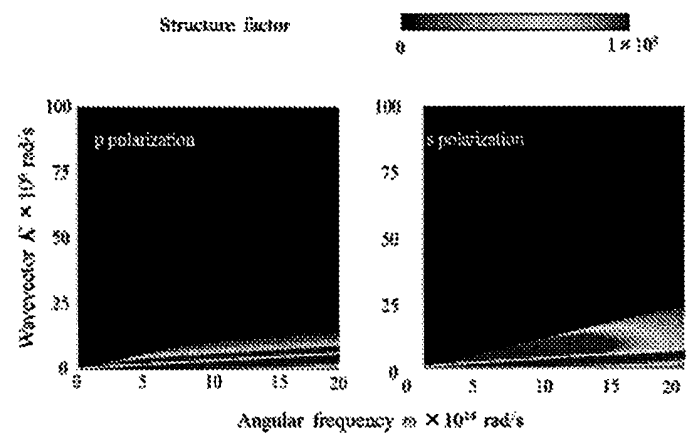

Fig. $4 \mathrm{p}$ and $\mathrm{s}$ polarized near-field radiative transfer between two semi-infinite plates made of Nickel and $\mathrm{GaSb}$

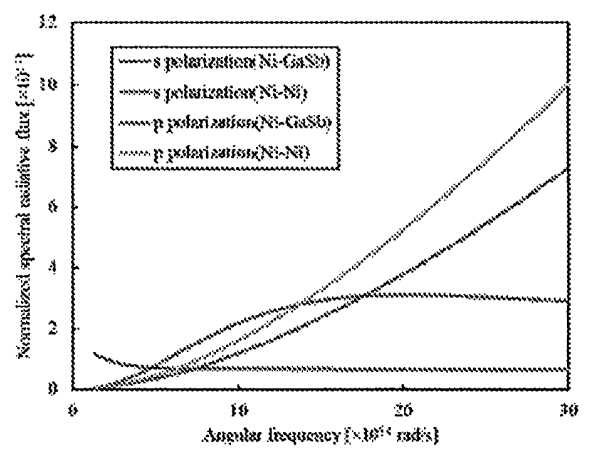

Fig. 5 Normalized spectral radiative flux between two semi-infinite plates made of nickel-nickel and nickel-GaSb

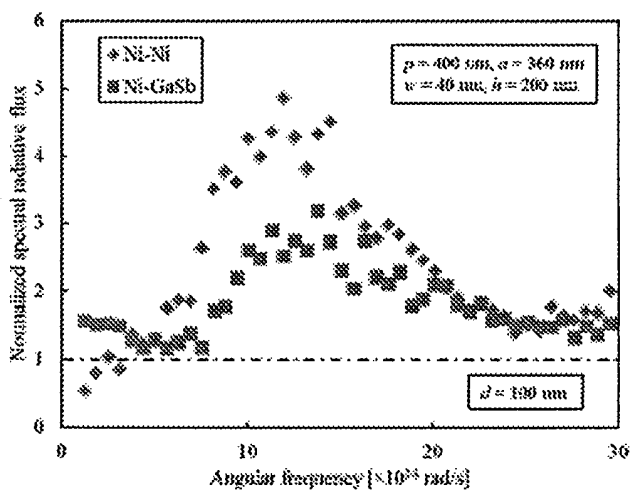

Fig.6 Normalized radiative flux between pillar array structures made of nickel and $\mathrm{GaSb}$ 